\title{
Online Cooperation in English Language Learning
}

\author{
Süleyman Ünal ${ }^{*} \quad$ Mehmet Gürol \\ Faculty of Education, Yıldız Technical University, PO box 34220, Davutpaşa, İstanbul, Turkey
}

\begin{abstract}
The purpose of this study aimed at examining the results of cooperative online activities in English Language Learning. This study is a quantitative study with experimental design. Random sampling method was used to determine learners and classes. Participants of this study were 229 English language learners in B1 level, 113 of whom are experimental group in 5 classes and 116 of whom are control group in 5 classes. Learners in experimental group followed a course design based on cooperative online activities and tasks for fifteen weeks. For data collection, a proficiency test named ALCPT was administered to learners at the beginning and end of the term as a pre-test and post-test. Cronbach alpha level of the test was found to be, 98. Reading, writing, listening, speaking, vocabulary and grammar achievement tests were implemented at the end of the semester. Data were analyzed with the help of SPSS 20 by employing descriptive and inferential statistics. Test of normality and homogeneity were calculated by applying Kolmogorov-Smirnova and Levene Statistic respectively. Results showed experimental group were significantly different in their proficiency test scores although there was no significant difference between control group and experimental group at the beginning of the semester in their pre- test proficiency test scores. Achievement test scores revealed that learners in experimental group did significantly better in listening, reading, writing and vocabulary achievement tests. However, there weren't significant differences in speaking and grammar achievement tests between two groups.

Keywords: cooperation, language learning, proficiency, achievement
\end{abstract}

DOI: $10.7176 / \mathrm{JEP} / 10-36-09$

Publication date: December $31^{\text {st }} 2019$

\section{Introduction}

There are various definitions of Cooperative Language Learning. Aydın (2009) defined cooperative language learning as a learning method in which learners come and work together for common purposes. In this language learning method, learners are in communication and interaction together and that's why relationship among learners are crucial. Doymuş (2007) stated that learners are more successful in cooperative language learning compared to other language learning methods. This method supports not only language learning of learners but also social, physiological and mental behaviours of learners. Learners have more time together and know each other more. Each learner is exposed different perspectives and point of views in cooperative language learning. This helps them have broader views.

Ekinci (2005) asserted that learners learn from each other in maximum level. Cooperative language learning helps learners develop tolerance, respect and negotiating skills which are must in daily life. Koçak and Akın (2008) stated that cooperative language learning brings learners together and help learners have lower level of language learning anxiety and maximize the success of learning. Since learning occurs in a sincere atmosphere, language learning experience get joyful and fun. Learners are less afraid to make mistakes and more volunteer to take initiatives.

Ün (2011) added that learners never feel themselves alone in cooperative language learning and make use of their peers and groups. Learners may get many instant feedbacks from their friends and have opportunity to correct themselves without in a more appropriate way. Learner, who has a problem in understanding particular topic or theme, may get immediate help from his friends. In return, he helps his friends when they are in need of help. Alıc1 (2010) also added that learners adapt to language learning atmosphere easily and without anxiety or fear. In cooperative language learning, it is really easy for teachers to keep learners on the same track. Şahin (2011) highlighted the importance of grouping learning because cooperative language learning should help learners work together efficiently and any problems to hinder this must be predicted in advance and taken necessary precautions. Byrd (2012) stated that learners develop group dependency when they create something together and feeling of belonging to a group is endorsed positively. Şahin (2011) stated that individuals, who have gone through cooperative learning experiences, are more ready for social life and have better at having problem solving skills, helping each other, constructing knowledge. They are also superior in high order cognitive skills such as analysis, synthesis and evaluation.

The purpose of this study aims at examining the results of cooperative online activities in English Language Learning. Particularly, this study investigates to what extent study cooperative online activities make difference in the proficiency and achievement scores of experimental and control groups. As a parallel to purpose of the research, three research questions were put forward below:

1. Is there a significant difference between control group and experimental group in their pre-test scores? 
2. Is there a significant difference between control group and experimental group in their post-test proficiency scores?

3. Is there a significant difference between control group and experimental group in their post-test achievement scores?

This study will contribute a lot to literature because not enough study has been conducted in the literature to study online tools for cooperative purposes for such a long term and analyse the result.

\section{Method}

This study is a quantitative study with experimental design. Creswell (2012) describes experimental design as a research which provides cause effect relationship among a group of variables in a research study by studying a sample of that population. Random sampling method was used to determine learners. Creswell (2012) defined random sampling as a sampling in which each individual has equal chance to be chosen for the purpose of the study.

\subsection{Setting and Participants}

Participants of this study were 229 learners, 116 of whom are in the control group in 5 classes and 113 of whom are in the experimental group in 5 classes. This study was conducted in a state university in Istanbul, Turkey. Learners came from different background and they were graduates of various high school in Turkey. All of the learners were sophomores at that time of the study. They were grouped as A2 level in the admission period in the previous years. Learners who didn't have A2 level weren't admitted as a Freshman and they were sent to PrepClass. At the end of the first year, learners had A2 level language test and learners who didn't have enough scores had to study the same class again. All the learners were grouped into 10 classes heterogeneously. Classes out of ten classes were chosen for the study randomly and 5 of them were selected as experimental group and 5 of them were determined as control group. Learners were at the A2- B1 levels and Control group followed Speak out Intermediate by Pearson Press as a course book while experimental group followed an English course design based on cooperative language learning activities and tasks. Learners had 8 hours of English Language instruction during two semesters.

\subsection{Data Collection}

In order to reach the aim of the study, ALCPT (American Language Course Placement Test) were administered to learners in both groups. ALCPT test system is developed and used by American Defence Ministry in order to determine the personnel for various tasks in NATO mission. ALCPT test system includes many forms of same level tests. Each form includes 66 listening items and 34 reading items. It focuses on the comprehension level of the test takers. In this study, two parallel forms were used as a pre-test and post-test.

Speaking, reading, writing, listening, vocabulary and grammar achievement tests were developed by the researchers. After taking experts' and colleagues' opinions for face and content validity, tests were revised. While preparing achievement tests, B1 level according to CEFR (Common European Framework OF Reference) was chosen as the level of the test. Some of the items were selected from Cambridge PET test. For the reading, listening, vocabulary and grammar tests, answer keys were prepared in advance and given the evaluators. For writing and speaking, rubrics were formed and given to evaluators. For the speaking, two evaluators evaluated each learner's speaking competency based on the criteria in the rubrics. Average scores of the two evaluators were accepted as the speaking achievement test score of each learner. Speaking and writing tests were evaluated out of 20. Grammar and vocabulary test were evaluated out of 25. Listening achievement test were 30 points while reading achievement test were 50 points. In total, all achievements tests were out of 170 .

\subsection{Data Analysis}

Data were analysed with the help of SPSS 20 by employing descriptive and inferential statistics. Results of the pre-test and post-test proficiency scores and achievement test scores were coded into SPSS. After data were checked whether there were missing values, descriptive statistics including frequency, percentage, mean and standard deviations were calculated. Requirements of able to use parametric statistics, were tested. Test scores were found to be normal and homogenous. Paired T-test and Independent T-test were implemented.

\subsection{Procedure}

During this study, learners in the control group followed a course book that belongs to private publishing company. Learners in the experimental group, however, followed an English Course Design based on cooperative language teaching activities and tasks. Online educational tools were used in the study. Tools used in the study were given figure 1 below: 


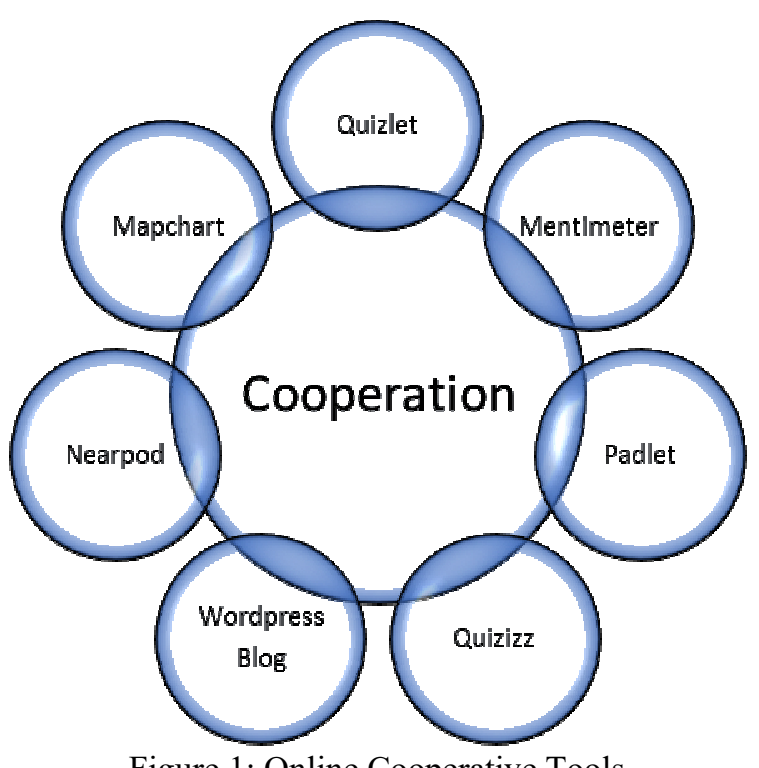

Figure 1: Online Cooperative Tools

Quizlet is an educational tool that offer variety of opportunities to develop vocabulary knowledge and in this study, it was mostly used for vocabulary teaching. Mentimeter is another tool used in the study and it was mostly used for writing and speaking skills. Padlet is a platform in which users may share what they create and they get immediate feedback via voting, commenting and pointing by other readers. Only people who have classroom code may reach the content. It was mostly used for writing and speaking in this study. Quizizz is another tool used and it was mostly used for vocabulary, grammar and reading activities. Wordpress Blog is a platform in which users share what they create and the content may be followed by any person who has access to Internet. Nearpod is an interactive classroom presentation tool. It was mostly used for reading and listening. Mapchart is an educational website which offers maps and opportunities to make some changes on the maps by colouring, numbering and bordering. In this study, it was used for gamification purposes.

\subsection{Reliability and Validity}

With the help of SPSS, reliability scores of the test was found to be 98 . This Cronbach Alpha value were higher than the accepted value in the literature, which is ,70. After reliability calculation, to use the parametric statistic, Test of normality value through Kolmogorov-Smirnova and Shapiro-Wilk test was calculated and test scores were found to be normal. Levene statistic for Test of Homogeneity of Variances was implemented and the result showed that test scores was homogenous as well.

\section{Findings}

As parallel to research questions raised for this study, three tables were prepared below. Table 1 was created to find answer to first research question. Table 2 were prepared to address second research question and Table 3 were seeking an answer to third research question in the study.

First research question sought an answer to whether control group and experimental group differed significantly in their pre-test scores. Result were presented below.

Table 1. Pre-Test Proficiency Scores

\begin{tabular}{llllll}
\hline Group & Number & Mean & S. Dev & Dif. & Sig. \\
\hline 1 & 113 & 40,34 & 9,87 & $-1,45$ &, 243 \\
2 & 116 & 41,79 & 8,80 & & \\
\hline
\end{tabular}

As it is seen from the table above, 113 learners were in experimental group and 116 learners were in control group. Mean scores from the American Language Placement Test were found to be 40,34 for experimental group, 41,79 for control group respectively. Significance level of the means were ,243. This meant there wasn't a significant difference in the pre-test scores of experimental and control groups. This showed that both parties had approximately the same level of language proficiency.

In order to find an answer to second research question, Table 2 was formed below by using post test scores of the proficiency test used in the study.

Table 2. Post-Test Proficiency Scores

\begin{tabular}{llllll}
\hline Group & Number & Mean & S. Dev & Dif. & Sig. \\
\hline 1 & 113 & 62.77 & 7.31 & 5,57 &, $001^{*}$ \\
2 & 116 & 57.29 & 7.56 & & \\
\hline
\end{tabular}


Posttest proficiency test scores showed that average mean scores for experimental group 62,77 while it was 57,29 for the control group. It means there was 5,57 mean difference between control group and experimental group. Significance value showed that this mean difference was significant. Although there wasn't a significant difference in the pre-test proficiency scores, post-test scores are significantly different. It can be inferred that the English course design based on cooperative online activities help learners in experimental do better in the proficiency test.

Third research question sought an answer to whether the course design caused significant difference in the achievement test scores of the both groups. For this purpose, mean, standard deviation, mean difference between two groups and significance value of the achievement scores for each skills and system were calculated. The results were given in the table below.

Table 3. Achievement Scores

\begin{tabular}{|c|c|c|c|c|c|c|}
\hline & Group & Number & Mean & S. Dev & Difference & Sig. \\
\hline \multirow[t]{2}{*}{ Speaking (20) } & 1 & 113 & 15.14 & 2.70 & \multirow{2}{*}{,39 } & \multirow{2}{*}{,228 } \\
\hline & 2 & 116 & 14.75 & 2.17 & & \\
\hline \multirow[t]{2}{*}{ Listening (30) } & 1 & 113 & 14.92 & 4.31 & \multirow{2}{*}{2,49} & \multirow{2}{*}{, 001} \\
\hline & 2 & 116 & 12.43 & 3.37 & & \\
\hline \multirow[t]{2}{*}{ Writing (20) } & 1 & 113 & 14.56 & 2.47 & \multirow{2}{*}{2,44} & \multirow{2}{*}{, 001} \\
\hline & 2 & 116 & 12.12 & 2.81 & & \\
\hline \multirow[t]{2}{*}{ Reading (50) } & 1 & 113 & 32.97 & 6.24 & \multirow{2}{*}{3,36} & \multirow{2}{*}{, 001} \\
\hline & 2 & 116 & 29.61 & 5.69 & & \\
\hline \multirow[t]{2}{*}{ Grammar (25) } & 1 & 113 & 14.65 & 3.30 & \multirow{2}{*}{, 13} & \multirow{2}{*}{,782 } \\
\hline & 2 & 116 & 14.52 & 3.73 & & \\
\hline \multirow[t]{2}{*}{ Vocabulary (25) } & 1 & 113 & 14.86 & 3.71 & \multirow{2}{*}{1,72} & \multirow{2}{*}{, 001} \\
\hline & 2 & 116 & 13.14 & 3.83 & & \\
\hline \multirow[t]{2}{*}{ Total (170) } & 1 & 113 & 107.12 & 11.66 & \multirow{2}{*}{10,53} & \multirow{2}{*}{,001 } \\
\hline & 2 & 116 & 96.59 & 11.37 & & \\
\hline
\end{tabular}

Listening achievement test scores showed that average mean for experimental was 14,92 whereas it was 12,43 for control group. It can be inferred from the significance value, there is significant difference in the listening test scores of both groups. Writing and reading scores of the both groups showed that there were significant differences in the both group and both tests because each significance value is lower than 0,05 . In addition, vocabulary achievement test scores showed that there was significant difference in the experimental and control group. Total average achievement scores of the both groups also showed that there was a significant difference between both groups.

However; when speaking achievement scores were analyzed, average mean for experimental group was 15,14 ; it was 14,75 for the control group. Significance value showed that there wasn't a significant difference in the speaking achievement test scores between control group and experimental group. Average grammar achievement test scores for experimental and control group wasn't significantly different contrary to test scores of reading, writing, listening and vocabulary achievement test scores.

Therefore, it can be inferred that the English course design based on cooperative online activities help learners in experimental group do significantly better in listening, reading, writing and vocabulary achievement test scores. However, it didn't cause the same impact on the speaking and grammar achievement test scores.

\section{Discussion, Conclusion and Suggestions}

This study was conducted in a state university in Turkey. The purpose of the study was to investigate to what extent the English course design based on cooperative online activities affected the proficiency and achievement tests scores of the learners. Proficiency test result showed learners in experimental group are significantly better in the post test result although there wasn't a significant difference between two groups. Achievement tests scores also give idea about the efficiency of course design. Although speaking and grammar achievement test scores doesn't reveal a significant difference between control and experimental groups, listening, reading, writing and vocabulary achievement test scores shows learners in experimental group got significantly better grades than learners in control group.

In the literature, it is possible to find supporting and contradicting results in the literature. However, studies supporting the findings are far more than the studies that contradict the results in this study. For example, Hung, Mehl and Holen (2013) stated that learners in cooperative language classrooms are better at communication and interaction. Johnson and Johnson (2013) suggested that when learners are in cooperative language atmosphere, they learn how to communicate well and help each other to have better language skills. They also suggested that cooperative language activities help learners develop their creativity other than improving language capacity. 
Benson (2011), who is known as the father of learner autonomy expressed that learners learn to behave more autonomously in cooperative language classes and since they feel responsible for their own learning, they start to develop their proficiency. Ma and Gao (2010) put forward similar results as Benson (2011). They asserted that when language learners cooperate, they start to become more autonomous and in return, they develop more responsibilities for their own learning. Murphy (2008) expressed that the more learners involve in cooperative language activities, the more they enjoy and they are actively engaged in the lessons.

As mentioned above, there are studies in the literature that contradict what this study suggested as findings. Radwan (2011), for example, investigated the cooperative language learning effect on language learning. He found that learners didn't show better oral language performance although learners expressed that they felt more comfortable and motivated in cooperative language learning. Ke and Grabowski (2007) compared the traditional language learning and cooperative language learning. They suggested that cooperative language learning didn't cause a significant difference in the academic success of the learners. Gaith (2003) studied the effect of cooperative learning on reading development, academic self- efficacy and reducing alienation. He found significant difference in reading skill development, however; it didn't cause significant difference in academic self-efficacy and reducing alienation.

This study is a quantitative study with an experimental research design. The result of this study should be supported with qualitative data. Semi structured interviews may be held to gain more insight about the benefits of cooperative online activities. For further studies, how cooperative online activities affect the self-efficacy and language learning autonomy may be studied. As it is known developing 21 st century skills are hot topic recently. Therefore; it may also be studied how online cooperative activities in language learning influence the development 21 st century skills as well.

\section{References}

Alıcı, D. (2010). Öğrenci Performansının Değerlendirilmesinde Kullanılan Diğer Ölçme Araç ve Yöntemleri. S. Tekindal (Ed.), Eğitimde Ölçme ve Değerlendirme (127- 168). (2. Baskı). Ankara: Pegem A. Yayıncılık.

Aydın, F. (2009). İşbirlikli Öğrenme Yönteminin 10. Sınıf Coğrafya Dersinde Başarıya, Tutuma ve Motivasyona Etkileri. Yayınlanmamış Doktora Tezi, Gazi Üniversitesi Eğitim Bilimleri Enstitüsü, Ankara.

Benson, P. (2011). Teaching and Researching Autonomy, Second Edition. Harlow: Pearson Education Limited

Byrd, D. (2012). Social studies education as a moral activity: Teaching towards a just society. Educational Philosophy and Theory, 44 (10), 1073-1079.

Creswell, J. W. (2012). Educational research: Planning, conducting, and evaluating quantitative and qualitative research (4th ed.). Boston, MA: Pearson.

Doymuş, K. (2007). Effects of A Cooperative Learning Strategy on Teaching And learning Phases of Matter and One-Component Phase Diagrams, Chemical Education Research, 84 (11), 1857-1860.

Ekinci, N. (2005). İşbirliğine Dayalı Öğrenme. Eğitimde Yeni Yönelimler. Ed. Demirel, Ö. (Ed.). Pegem A Yayınc1lık, Ankara.

Gaith, G.H. (2003). Effects of the Learning Together Model of Cooperative Learning on English as Foreign Language Reading Achievement, Academic Self-Esteem, and Feeling of School Alienation. Bilingual Research Journal, 27(3), 451-474.

Hung, W., Mehl, K. and Bergland Holen, J. (2013). The relationship between Problem Design and Learning Process in Problem-Based Learning Environment: Two Cases. The Asia-Pacific Education Researcher, 22(4), 635- 645.

Johnson, D. W., \& Johnson, F. P. (2013). Joining together: Group theory and group skills (11th ed.). Boston, MA: Pearson.

Ke, F., \& Grabowski, B. (2007). Gameplay for maths learning: cooperative or not? British Journal of Educational Technology, 37, 249-259.

Koçak, R. and Akın, U. (2008), Kubaşık Öğrenme Yönteminin Üniversite Öğrencilerinin Matematik Başarılarına ve Bazı Sosyal Özelliklerine Etkisi, Eğitim Bilimleri ve Uygulama, 7 (13).

Ma, Z. and Gao, P. (2010). Promoting Learner Autonomy through Developing Process Syllabus - Syllabus Negotiation: the basis of Learner Autonomy. Journal of Language Teaching and Research. 1(6), 901-908

Murphy, L. (2008). Supporting learner autonomy: Developing practice through the production of courses for distance learners of French, German and Spanish, Language Teaching Research, 12(1), 83-102

Radwan, A.A. (2011). Effects of L2 proficiency and gender on choice of language learning strategies by university students majoring in English. Asian EFL Journal, 13(1), 114-162.

Şahin, A. (2011). İş birlikli öğrenme teknikleri ve Türkçe öğretimi, (I. Basım), Ankara, Pegem A. Yayınları 